\title{
Salinity and Water Temperature as Predictors of Bottlenose Dolphin (Tursiops truncatus) Encounter Rates in Upper Galveston Bay, Texas
}

\author{
Vanessa J. Mintzer ${ }^{1,2,3 * t}$ and Kristi L. Faziolit ${ }^{4 t}$
}

1 Galveston Bay Foundation, Kemah, TX, United States, ${ }^{2}$ Fisheries and Aquatic Sciences Program, School of Forest, Fisheries, and Geomatics Sciences, University of Florida, Gainesville, FL, United States, ${ }^{3}$ Wildlife Research Partnerships, Asheville, NC, United States, ${ }^{4}$ Environmental Institute of Houston, University of Houston - Clear Lake, Houston, TX, United States

\section{OPEN ACCESS}

Edited by:

Lars Bejder,

University of Hawai'i at Mānoa,

United States

Reviewed by:

Natascha Wosnick,

Federal University of Paraná, Brazil

Holly Raudino,

Department of Biodiversity,

Conservation and Attractions (DBCA),

Australia

*Correspondence:

Vanessa J. Mintzer

vmintzer@galvbay.org;

vjs@ufl.edu

${ }^{t}$ These authors have contributed equally to this work and share first authorship

Specialty section:

This article was submitted to

Marine Megafauna,

a section of the journal

Frontiers in Marine Science

Received: 06 August 2021

Accepted: 12 October 2021

Published: 17 November 2021

Citation:

Mintzer VJ and Fazioli KL (2021)

Salinity and Water Temperature as

Predictors of Bottlenose Dolphin (Tursiops truncatus) Encounter Rates

in Upper Galveston Bay, Texas.

Front. Mar. Sci. 8:754686.

doi: 10.3389/fmars.2021.754686
Bottlenose dolphins (Tursiops truncatus) that inhabit urban estuaries like Galveston Bay, Texas, are exposed to cumulative stressors including pollution, fisheries, shipping, freshwater inflows, and construction operations. With continuing development, it is imperative to understand the key environmental variables that make the Galveston Bay estuary suitable habitat for this protected species. The Galveston Bay Dolphin Research Program conducted monthly photo identification surveys of bottlenose dolphins in a previously understudied $186 \mathrm{~km}^{2}$ area in upper Galveston Bay (UGB). To understand occurrence patterns in this region, we calculated monthly encounter rates of dolphins (dolphins/km) for four consecutive years (2016-2019). Using multiple linear regression models, we investigated the relationship between encounter rates, and water temperature and salinity. Monthly encounter rates ranged from 0.00 to 1.23 dolphins $/ \mathrm{km}$ with an average of 0.34 dolphins $/ \mathrm{km}$ (SE $=0.05$ ). Over $80 \%$ of the variance was explained by the predictor variables water temperature and salinity $\left(R^{2}=0.820\right)$. Water temperature had a positive linear effect on encounter rates at over $23.37^{\circ} \mathrm{C}(\mathrm{SE}=1.42)$. Accordingly, higher encounter rates occurred during months with warm temperatures (May-September) compared to cooler months (NovemberApril), indicating a predictable yearly movement pattern. Moreover, salinity was a highly significant predictor variable, with encounter rates dropping linearly with decreases in salinity. Higher numbers of dolphins are found in UGB during summer, but an exodus of dolphins occurs with low salinity levels, regardless of the time of year and water temperature. These findings should be considered during infrastructure projects (i.e., flood gate system) that may alter dolphin habitat and prey availability.

Keywords: marine mammals, seasonal movement, freshwater influx, environmental factors, industrial estuary, low salinity, flooding events, Gulf of Mexico

\section{INTRODUCTION}

Bottlenose dolphins (Tursiops truncatus) are commonly found in bay, sound, and estuarine environments (Leatherwood and Reeves, 2012; Vollmer and Rosel, 2013; Phillips and Rosel, 2014; Wells and Scott, 2018). These dynamic water bodies, where freshwater mixes with seawater, are among the Earth's most biologically productive systems (Kennish, 2002). 
However, due to coastal population growth and rapid development, many estuaries are severely impacted by anthropogenic activities (Kennish, 2002). Bottlenose dolphins that inhabit urban and industrialized estuaries are exposed to diverse stressors including pollution, commercial and recreational fisheries, shipping, dredging and construction, algal bloom, and freshwater inflows (Phillips and Rosel, 2014).

Galveston Bay, Texas is one of the most industrialized estuaries in the United States. Its watershed supports half the population of Texas, and it contains the highest concentration of oil refineries and petrochemical plants in the world [Houston Advanced Research Center (HARC), 2020; GBRC, 2021]. These industries rely on the Houston Ship Channel (HSC) for transportation, leading to heavy year-round ship and barge traffic. Severely impaired water quality prior to 1970 placed portions of upper Galveston Bay (UGB) on the list of the Environmental Protection Agency's top 10 most polluted water bodies (Youngblood, 2010). Corrective measures have improved water quality over time, but concerns remain over high concentrations of contaminants in sediment and biota [Phillips and Rosel, 2014; Houston Advanced Research Center (HARC), 2020; and sources therein]. Moreover, proposed large infrastructure projects, involving coastal protection barriers (USACE and TGLO, 2021), could further impact wildlife habitat in Galveston Bay.

Prior to this study, most research on common coastal bottlenose dolphins (herein referred to as "dolphins") in Galveston Bay focused on describing dolphin activity in the southern portion of Galveston Bay, primarily in or adjacent to "Bolivar Roads" (the inlet that connects the Bay to the Gulf of Mexico) (e.g., Henningsen and Würsig, 1991; Bräger et al., 1994; Fertl, 1994; Moreno and Mathews, 2018). This area has been consistently described as having a high concentration of dolphins (Henningsen and Würsig, 1991; Moreno and Mathews, 2018; Ronje et al., 2020). On the other hand, few studies focused on waters of the inner estuary and upper portions of the Bay, and observational surveys conducted in the 1980s-1990s resulted in few or no dolphin sightings in UGB (Jones, 1988; Henningsen and Würsig, 1991; Blaylock and Hoggard, 1994). An apparent "South-North decrease" of dolphins in the Galveston Bay estuary has been attributed to the higher concentrations of prey near the mouth of the estuary, as well as higher levels of contaminants in UGB (Moreno, 2005). Nevertheless, anecdotal data from longterm Galveston Bay users (i.e., boaters, fishers) suggests that dolphin abundance may have increased in UGB over the last few decades (Fazioli et al., 2016). Reconnaissance surveys conducted in 2013-2014 confirmed the frequent presence of dolphins in western UGB and led to the establishment of a long-term monitoring program focused on this previously understudied area.

Increased dolphin activity in this area may reflect the success of efforts to protect Galveston Bay; however, development in the region continues and habitat degradation persists (Youngblood, 2010; Phillips and Rosel, 2014; and sources therein). Accordingly, the Galveston Bay bottlenose dolphin stock [as defined by National Oceanic and Atmospheric
Administration Fisheries (NOAA Fisheries)] has been designated as high priority for research and monitoring (Phillips and Rosel, 2014). Information on habitat use, abundance, site fidelity, and stock structure are all needed to better inform management and conservation of these federally protected dolphins (Phillips and Rosel, 2014; Hayes et al., 2019). Moreover, in the face of anthropogenic and climatic changes affecting the Bay, it is imperative to understand the key environmental factors that make the estuary suitable dolphin habitat.

A variety of biotic and abiotic factors influence bottlenose dolphin abundance and distribution. These may include but are not limited to prey and predator distribution, intraspecific social dynamics, topography, turbidity, temperature, and salinity (Irvine et al., 1981; Hastie et al., 2006; Heithaus and Dill, 2006; Mazzoil et al., 2008; Huther, 2010; Hornsby et al., 2017; Moreno and Mathews, 2018). In Galveston Bay, Moreno (2005) observed dolphins further north of Bolivar Roads only June through August, the months with the warmest annual water temperatures. Ronje et al. (2020) indicated a summer increase in overall abundance for Galveston Bay, encountering more dolphin groups in UGB and shallow waters of the estuary during these months, and noting a density shift to deeper channel and Gulf pass habitats during the winter. Anecdotal data gathered from Bay-users also indicated a perceived increase in the number of dolphins present in UGB during summer months (Fazioli et al., 2016). This apparent increase coincides with the months of greater fish diversity in UGB (Bechtel and Copeland, 1970). In terms of salinity, UGB is marginal dolphin habitat, often fluctuating to below estimated $8-11 \mathrm{ppt}$ physiological tolerance thresholds (Ewing et al., 2017; Hornsby et al., 2017; Fazioli and Mintzer, 2020; McClain et al., 2020). A study focused on the effects of Hurricane Harvey, identified a decline in dolphin encounter rates in UGB during the prolonged period of low salinity after the storm (Fazioli and Mintzer, 2020). Herein, we focused on evaluating the relationship between dolphin presence in western UGB and two likely influential abiotic factors: temperature and salinity.

Given the expected continued anthropogenic development in Galveston Bay, we aim to increase knowledge about this understudied dolphin stock to inform future management and conservation efforts. To understand the occurrence patterns of dolphins in UGB, we calculated monthly encounter rates of dolphins (dolphins $/ \mathrm{km}$ ) for four consecutive years. Specifically, we aimed to (1) investigate if dolphins are found year-round in western UGB, and (2) evaluate the effect of temperature and salinity on dolphin presence in UGB.

\section{METHODS}

\section{Study Area and Survey Protocols}

This study took place in a $186 \mathrm{~km}^{2}$ area in western UGB, with land and the HSC delineating the western and eastern boundaries of the study area (Figure 1). The area is comprised primarily of shallow open water and man-made shipping channels (up to 15 m deep) [Houston Advanced Research Center (HARC), 2020]. 
Temperatures in the study area vary in accordance with the subtropical climate, with the lowest temperatures occurring December through February and the warmest in July and August [Houston Advanced Research Center (HARC), 2020]. Freshwater inflow, primarily from the Trinity and San Jacinto Rivers, largely affects the salinity of the study area (Orlando et al., 1993). April through June has been noted as a time of year with high inflow and corresponding low salinity (Orlando et al., 1993). The low flow season has been identified as July through October but can be interrupted with tropical storms (Ward and Armstrong, 1992). Moreover, these patterns are influenced by global-scale climatic processes (e.g., El Niño and the Southern Oscillation; Tolan, 2007).

The Galveston Bay Dolphin Research Program (GDRP) began to conduct boat-based dolphin surveys in UGB in 2013. In 2015-2016, we standardized the primary study area and survey protocols to allow for consistent long-term monitoring of the dolphin population. Herein, we utilized data gathered during continuous monthly boat-based surveys conducted from January 2016 to December 2019 under NOAA Fisheries Scientific Research Permit \#18881.

Monthly photo-identification surveys were conducted by 3-5 trained observers from a 7 to $8 \mathrm{~m}$ center console boat traveling at $18.5-32 \mathrm{~km} / \mathrm{h}$. Meandering survey routes were determined daily based on existing survey coverage and weather conditions (Wells et al., 1996; Urian et al., 2009) and were designed to achieve balanced coverage of nearshore, open bay and deep channel habitats within the study area (Supplementary Figures 1-4). Initial route direction was randomized to avoid diurnal biases (Rosel et al., 2011). It typically took 2-3 field days of effort to achieve coverage of the study area (Figure 1). Field days were completed consecutively, or as close together as weather would permit. When a dolphin was spotted, the crew stopped and took photographs of each dolphin's dorsal fin (for individual identification) and recorded data including location, dolphin activity, human interactions, group size, presence of calves, surface water quality (water temperature and salinity), tide, sea state, weather, and sighting conditions. Observers evaluated and rated sighting conditions from excellent to poor, by considering the combination of sea state, glare, and weather to determine the overall likelihood of seeing dolphins, if present, within $0.5 \mathrm{~km}$ of the boat. A sighting "group" was defined as all dolphins within approximately $100 \mathrm{~m}$ of each other, engaged in similar activities (Irvine et al., 1981). Standard photo-analysis tools and methodology were used to rate photo quality and fin distinctiveness and catalog individual dolphins in each sighting (Würsig and Würsig, 1977; Scott et al., 1990; Adams et al., 2006; Rosel et al., 2011; Urian et al., 2015).

During each survey day, the crew utilized a YSI Pro-DSS or 600 XLM Sonde to collect profiles (at $0.3 \mathrm{~m}$ from the bottom, mid-column and $0.3 \mathrm{~m}$ from the surface) of water temperature and salinity at "environmental profile stations" (Figure 1). Three to five stations were chosen each survey day to represent the areas surveyed regardless of the presence or absence of dolphins (Fazioli and Mintzer, 2020). To limit possible biases associated with stratification, only the average mid-column temperature and salinity readings were utilized for analysis.

\section{Encounter Rate Regression Analysis}

We calculated monthly dolphin encounter rates from January 2016 to December 2019. Monthly encounter rates were defined as the number of individual dolphins sighted per linear kilometer surveyed (dolphins $/ \mathrm{km}$ or $\mathrm{d} / \mathrm{km}$ ). Number of dolphins for each month were calculated by summing the best estimate, after photo-analysis, of dolphins in each group/sighting within the corresponding month (Supplementary Material 1). Resightings of individual dolphins within a given month were excluded. Overlay and measuring tools in ArcGIS Pro 2.5.0. were used to calculate the monthly linear effort $(\mathrm{km})$ within the study area polygon (Figure 1). Only sightings and linear effort that took place under sighting conditions rated as "good" or "excellent" were included in the calculations (Urian and Wells, 1996; Wells et al., 1996; Fazioli et al., 2006).

Using regression analyses, we investigated the relationship between encounter rates, and water temperature and salinity in UGB. We ran a multiple linear regression model, in Program $\mathrm{R}$ ( $\mathrm{R}$ Core Team, 2020), to predict encounter rates based on mid-column water temperature and salinity. Exploration of the data revealed a non-linear relationship between temperature and encounter rates. It also identified a likely interaction effect between salinity and temperature at high values. Consequently, we transformed the temperature values (temperature ${ }^{\wedge} 2$ ) to meet the linearity assumption of regression analysis, and we included the interaction effect. Thus, the model equation was:

\section{Encounter rates $(E R)=\beta_{0}+\beta_{1} *$ salinity $+\beta_{2} *$ temperature + $\beta_{3} *$ salinity $*$ temperature + $\beta_{4} *$ temperature $^{\wedge} 2$}

To further define the relationship between temperature and encounter rates, we also fit a regression model with segmented relationships to identify possible breaking points (Muggeo, 2008). A significance level of 0.05 was applied.

\section{RESULTS}

During the 4 years of this study (January 2016-December 2019), we completed $6655 \mathrm{~km}$ of survey effort in 105 field days. This resulted in the observation of 2388 dolphins in 355 groups (Figure 1 and Table 1). The overall average dolphin encounter rate was $0.34 \mathrm{~d} / \mathrm{km}(\mathrm{SE}=0.05)$. The annual average ranged from $0.28 \mathrm{~d} / \mathrm{km}(\mathrm{SE}=0.06)$ in 2019 to $0.44 \mathrm{~d} / \mathrm{km}(\mathrm{SE}=0.13)$ in 2018 (Table 1 and Figure 2). The highest monthly encounter rates occurred in August $2017(1.09 \mathrm{~d} / \mathrm{km})$ and August 2018 $(1.23 \mathrm{~d} / \mathrm{km})$ and the lowest was $0.00 \mathrm{~d} / \mathrm{km}$ calculated for 4 months throughout the study (February-April, Table 1 and Figure 2).

The average annual mid-column salinity ranged from 13.74 ppt $(\mathrm{SE}=1.38)$ in 2017 to $9.44 \mathrm{ppt}(\mathrm{SE}=1.26)$ in 2019 , with the lowest salinity recorded in June 2016 (1.51 ppt) and the highest in August 2018 (22.37 ppt) (Figure 2). Monthly water temperature ranged from a high of $31.65^{\circ} \mathrm{C}$ in August 2019 to a low of $9.99^{\circ} \mathrm{C}$ in January 2018 (Figure 2). The average annual water temperature was lowest in 2018 at $20.79^{\circ} \mathrm{C}(\mathrm{SE}=2.24)$, 


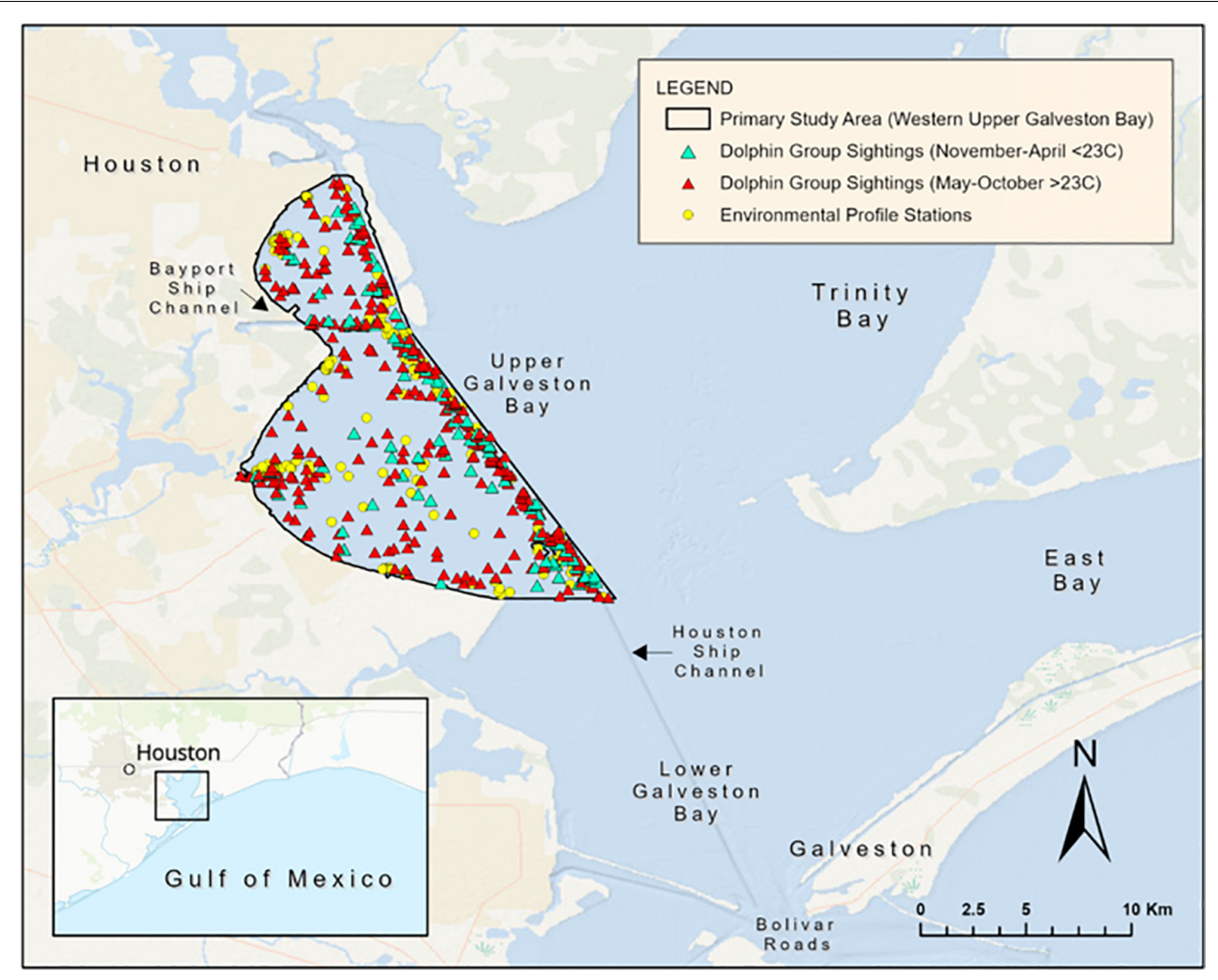

FIGURE 1 | Map of the primary study area in western upper Galveston Bay, Texas. Dolphin group sightings from January 2016 to December 2019 are displayed, as well as "Environmental Profile Stations" where mid-column water temperature and salinity were recorded. GIS layers: Esri, DeLorme, and NaturalVue.

while the warmest average water temperature was recorded in 2017 at $23.59^{\circ} \mathrm{C}(\mathrm{SE}=1.56)$.

The multiple regression equation was highly significant $[F(4,43)=49.02, p<0.000]$. Over $80 \%$ of the variance in encounter rates was explained by the predictor variables water temperature and salinity $\left(R^{2}=0.820\right)$. The interaction effect was significant $(p<0.001)$ confirming the need to include the interaction effect along with the main predictors (Supplementary Material 1). The segmented linear model identified a breaking point in the relationship between encounter rates and temperature, with temperature having a positive linear effect on encounter rates only at over $23.37^{\circ} \mathrm{C}(\mathrm{SE}=1.42$, Figure 3). The significant salinity coefficient $(p<0.001)$ in this model predicted a $0.02 \mathrm{~d} / \mathrm{km}$ encounter rate increase with every $1.00 \mathrm{ppt}$ increase in salinity (Figure 3 and Supplementary Material 1).

As indicated by the significant interaction effect between the two variables, the simultaneous/joint effect of temperature and salinity on encounter rates was significantly greater than the sum of the parts. The highest dolphin encounter rates in UGB were predicted to occur when both temperature and salinity were at their highest values. This was the case in August 2018 when encounter rates reached the peak of $1.23 \mathrm{~d} / \mathrm{km}$ (temperature $=29.97^{\circ} \mathrm{C}$, salinity $=22.37 \mathrm{ppt}$; Figure 2). In contrast, encounter rates were below average $(<0.34 \mathrm{~d} / \mathrm{km})$ in the warm months of June 2016, September 2017, and September 2019 when salinity reached below $3.5 \mathrm{ppt}$ due to heavy precipitation and the corresponding increase in freshwater inflows (Figure 2). This pattern was mirrored in the annual averages when in 2019 the lowest annual salinity $(\overline{\mathrm{x}}=9.44 \mathrm{ppt}, \mathrm{SE}=1.26)$ corresponded to the lowest annual encounter rates $(\overline{\mathrm{x}}=0.28 \mathrm{~d} / \mathrm{km}, \mathrm{SE}=0.06)$.

\section{DISCUSSION}

Our findings indicate that bottlenose dolphins can be found in UGB year-round, but most leave during the cooler months. Annually, encounter rates rise during months with the warmest water temperatures $\left(>23^{\circ} \mathrm{C}\right)$. Peak encounter rates will typically occur June-September; however, during periods of low salinity, encounter rates will likely decrease regardless of water temperature. Concurrent high temperature and salinity represent optimal environment conditions for dolphin presence in UGB.

As endothermic animals, dolphins depend on blubber and internal metabolic processes to maintain a stable body temperature. During the study period, dolphins experienced water temperature ranging from 10 to $32^{\circ} \mathrm{C}$. Coastal bottlenose dolphins generally tolerate this range with changes in integument thickness and whole body conductance (Meagher et al., 2008; Carmichael et al., 2012). However, temperature may be a limiting factor for smaller dolphins (i.e., juveniles, calves and their mothers) (Yeates and Houser, 2008; Carmichael et al., 2012). 
TABLE 1 | Number of boat-based field days, linear visual survey effort (km), number of bottlenose dolphins sighted (No. d), and corresponding encounter rates (ER, d/km) of bottlenose dolphins (Tursiops truncatus) in upper Galveston Bay, Texas from January 2016 to December 2019.

\begin{tabular}{|c|c|c|c|c|c|c|c|c|c|c|c|c|c|c|c|c|}
\hline \multirow[b]{2}{*}{ Month } & \multicolumn{4}{|c|}{2016} & \multicolumn{4}{|c|}{2017} & \multicolumn{4}{|c|}{2018} & \multicolumn{4}{|c|}{2019} \\
\hline & $\begin{array}{l}\text { No. field } \\
\text { days }\end{array}$ & $\begin{array}{c}\text { Effort } \\
\text { (km) }\end{array}$ & No. d & $\begin{array}{c}\text { ER } \\
(\mathrm{d} / \mathrm{km})\end{array}$ & $\begin{array}{l}\text { No. field } \\
\text { days }\end{array}$ & $\begin{array}{c}\text { Effort } \\
\text { (km) }\end{array}$ & No. d & $\begin{array}{c}\text { ER } \\
(\mathrm{d} / \mathrm{km})\end{array}$ & $\begin{array}{l}\text { No. field } \\
\text { days }\end{array}$ & $\begin{array}{c}\text { Effort } \\
\text { (km) }\end{array}$ & No. d & $\begin{array}{c}\text { ER } \\
(\mathrm{d} / \mathrm{km})\end{array}$ & $\begin{array}{l}\text { No. field } \\
\text { days }\end{array}$ & $\begin{array}{c}\text { Effort } \\
\text { (km) }\end{array}$ & No. d & $\begin{array}{c}\text { ER } \\
(\mathrm{d} / \mathrm{km})\end{array}$ \\
\hline January & 2 & 235 & 9 & 0.04 & 2 & 132 & 14 & 0.11 & 2 & 129 & 43 & 0.33 & 3 & 134 & 17 & 0.13 \\
\hline February & 2 & 162 & 13 & 0.08 & 2 & 126 & 0 & 0.00 & 2 & 129 & 3 & 0.02 & 2 & 111 & 5 & 0.05 \\
\hline March & 3 & 165 & 6 & 0.04 & 3 & 132 & 0 & 0.00 & 1 & 117 & 0 & 0.00 & 2 & 121 & 18 & 0.15 \\
\hline April & 1 & 112 & 11 & 0.10 & 1 & 89 & 0 & 0.00 & 2 & 133 & 19 & 0.14 & 1 & 16 & 0 & \\
\hline May & 2 & 130 & 4 & 0.03 & 1 & 64 & 3 & & 2 & 143 & 73 & 0.51 & 2 & 144 & 19 & 0.13 \\
\hline June & 2 & 175 & 34 & 0.19 & 2 & 141 & 115 & 0.81 & 3 & 153 & 148 & 0.96 & 2 & 153 & 62 & 0.41 \\
\hline July & 2 & 145 & 101 & 0.70 & 3 & 162 & 121 & 0.75 & 3 & 162 & 140 & 0.86 & 4 & 201 & 121 & 0.60 \\
\hline August & 2 & 135 & 115 & 0.85 & 2 & 105 & 115 & 1.09 & 3 & 124 & 152 & 1.23 & 2 & 139 & 94 & 0.67 \\
\hline September & 3 & 179 & 168 & 0.94 & 3 & 221 & 64 & 0.29 & 3 & 179 & 158 & 0.88 & 2 & 127 & 20 & 0.16 \\
\hline October & 2 & 120 & 67 & 0.56 & 2 & 117 & 25 & 0.21 & 2 & 122 & 35 & 0.29 & 2 & 128 & 28 & 0.22 \\
\hline November & 2 & 120 & 26 & 0.22 & 4 & 158 & 60 & 0.38 & 1 & 129 & 9 & 0.07 & 3 & 182 & 79 & 0.43 \\
\hline December & 2 & 135 & 3 & 0.02 & 2 & 141 & 27 & 0.19 & 2 & 141 & 2 & 0.01 & 2 & 137 & 42 & 0.31 \\
\hline Total & 25 & 1811 & 557 & & 27 & 1589 & 541 & & 26 & 1662 & 782 & & 27 & 1593 & 505 & \\
\hline
\end{tabular}

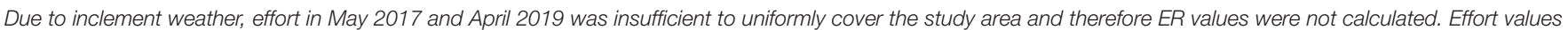
were rounded for presentation. Values reported for June to December 2016 and June to December 2017 were previously published in Fazioli and Mintzer (2020).

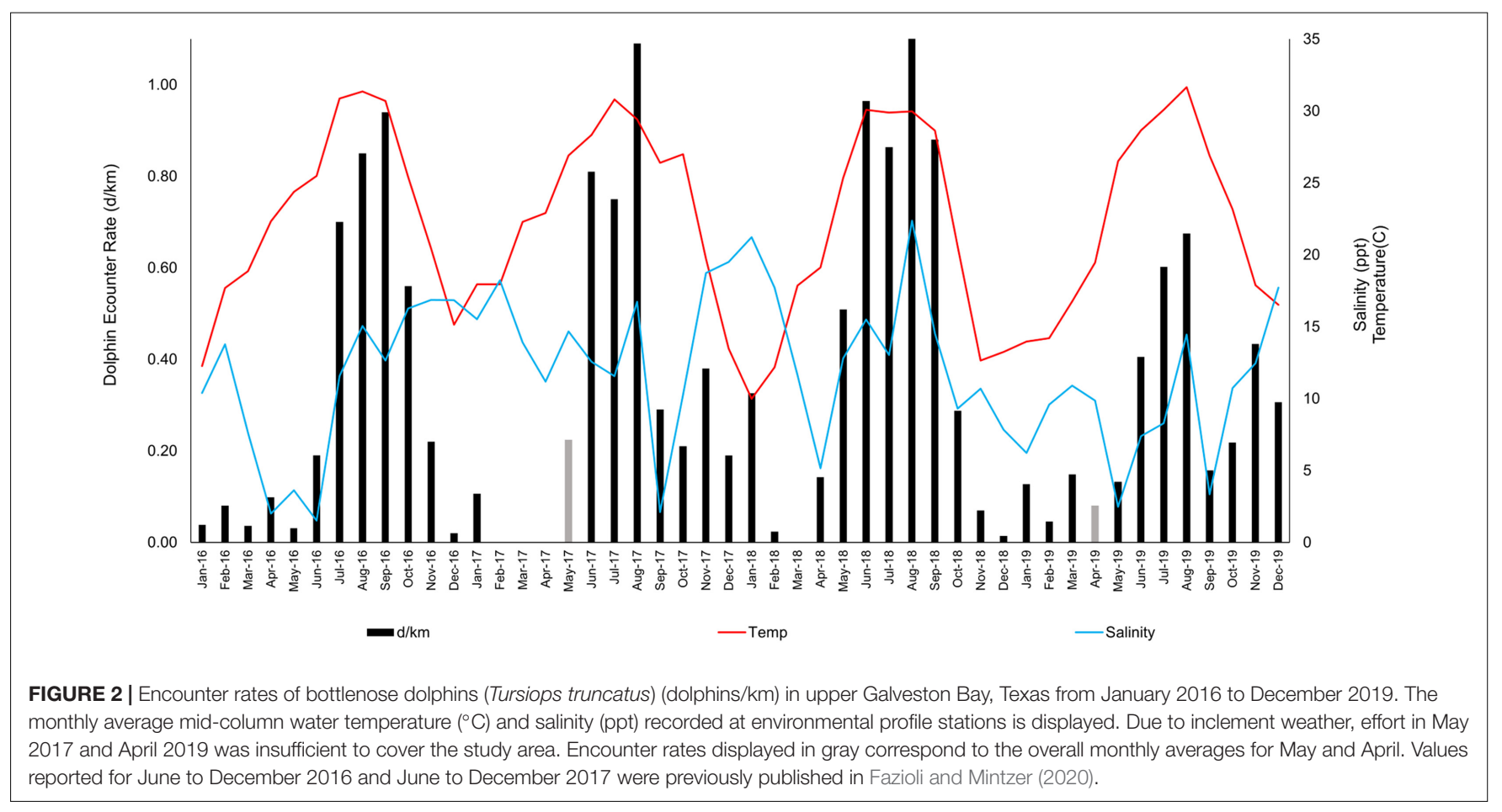

Exploratory analyses showed that mother/calf pairs can be found in the study area year-round, but the proportion of groups with calves was higher in the warm months $\left(>23^{\circ} \mathrm{C}\right)$ compared to the cold months $\left(<23^{\circ} \mathrm{C}\right)$. Peak calving season for dolphins in Texas coastal waters is in the spring (Urian et al., 1996; Fernandez and Hohn, 1998), coinciding with a time when fewer dolphins are present in UGB. Furthermore, sightings of early neonates in UGB are rare (GDRP, unpublished data). If mothers with neonates frequent the study area only during warm months due to their offspring's metabolic constraints, this could, in part, explain the effect of temperature on encounter rates. The drivers of movements and habitat use of mother/calf groups and calving females should be studied.

Prey migration is likely an important underlining mechanism for the annual encounter rate patterns related to temperature fluctuations (Irvine et al., 1981; Scott et al., 1990; Wilson et al., 1997). In and near Sarasota, Florida, for example, dolphins are found inside bays year-round, but many shift their distribution 

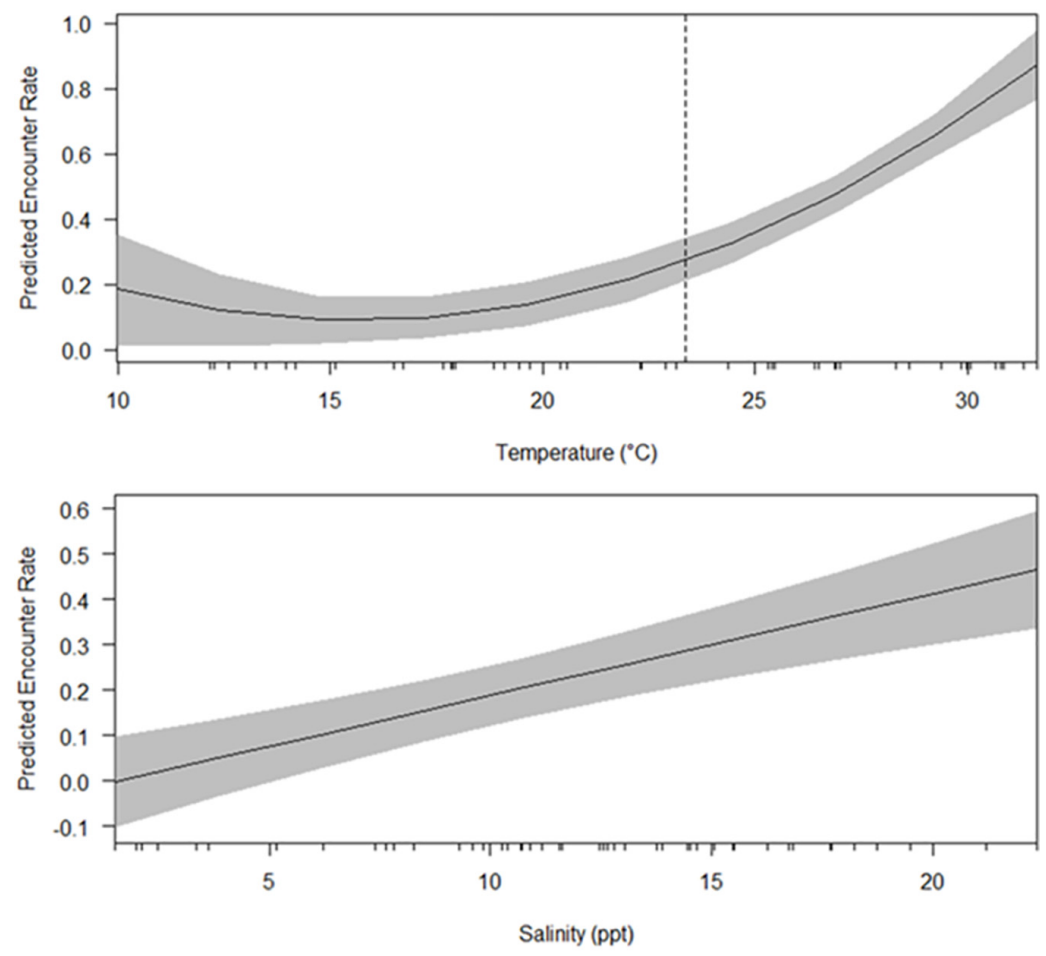

FIGURE 3 | Predicted encounter rates (dolphins/km) of bottlenose dolphins (Tursiops truncatus) in upper Galveston Bay, Texas resulting from a multiple regression model with water temperature $\left({ }^{\circ} \mathrm{C}\right.$ ) and salinity (ppt) as predictor variables. Tick marks on $x$-axis represent observed values. $\mathrm{A}$ breaking point of $23.37^{\circ} \mathrm{C}(\mathrm{dashed}$ line) identified by segmented linear regression is displayed.

toward the Gulf during cooler months (Scott et al., 1990). Mullet migration has been suggested as a primary factor for this change, as mullet migrate from inshore areas to the Gulf to spawn in the fall and return to the bays in the spring (Scott et al., 1990). A similar pattern occurs in Texas where mullet leave the bays, from October to January, to spawn 40-50 miles offshore (Boyd, 2011). For many Galveston Bay fish species, two migration patterns have been recorded: the migration of spawning adults leaving the Bay and the migration of postlarvae and juveniles entering the Bay (Bechtel and Copeland, 1970). Although the exact timing of these migrations varies by species, most correspond with seasonal temperature changes and many enter the Bay as the temperature increases (Bechtel and Copeland, 1970). Additionally, a commercial shrimp fishery operates within the estuary, with trawler activity increasing in UGB during warm months, following shrimp life cycle and migration patterns [TWPD, 2002; Houston Advanced Research Center (HARC), 2020]. The strong association of foraging dolphins with this fishery (Henningsen and Würsig, 1991; Fertl, 1994; Moreno, 2005; Piwetz, 2019) has the potential to affect dolphin movements. Accordingly, dolphins likely return to UGB with rising water temperatures due to a combination of factors related to food availability.

Our results suggest that the UGB study area does not encompass the entire home ranges of the observed dolphins. Many individuals known to frequent UGB have been sighted south of our study area, in lower Bay, during the cooler months of the year (GDRP, unpublished data). However, it is unknown if most remain in the lower Bay or if they leave the estuary to utilize nearby coastal waters, or travel to other estuaries. Travel between Texas bays has been documented in other studies for some individuals (Blaylock and Hoggard, 1994; Maze and Würsig, 1999; Lynn and Würsig, 2002; Ronje et al., 2020). Previous studies have identified changes in abundance aligning with annual temperature fluctuation in studies in Galveston and other Texas estuaries (Shane, 1980; Henningsen and Würsig, 1991; Fertl, 1994; Wilson et al., 1997; Ronje et al., 2020). As in UGB, dolphin abundance peaks during the summer in other northern Texas coastal locations and decreases with cooler temperatures (Fertl, 1994; Wilson et al., 1997; Ronje et al., 2020), while in central and south Texas the opposite pattern has been documented (Shane, 1980; McHugh, 1989). Telemetry studies will be required to map detailed range patterns, but future winter observational studies focused on lower Galveston Bay could help determine if most UGB dolphins remain in the estuary during the cooler months and could identify calving hotspots.

During the study period, most dolphins left the study area during low salinity events (i.e., when salinity dropped below 8-11 ppt) and returned once salinity level had increased. This trend was evident in June 2016 (“Tax Day Flood"), September 2017 (Hurricane Harvey), and September 2019, when heavy precipitation led to salinity levels below $3.5 \mathrm{ppt}$ and encounter rates dropped well below expected levels for the time of year. 
2018 was the only year covered in this study with no major low salinity event, and it had the highest annual encounter rate of $0.44 \mathrm{~d} / \mathrm{km}$. On the other hand, 2019, a year with an El Niño event, had an exceptionally wet spring and early summer (TWDB, 2021) likely explaining the relatively lower encounter rates during these months and the annual average of only $0.28 \mathrm{~d} / \mathrm{km}$. Although more research is needed to understand the mechanisms behind the apparent exodus of dolphins from the study area at low salinity, it is likely that reduced prey availability is a driver since many estuarine fish species emigrate to higher salinity water during freshwater events (Greenwood et al., 2006; Taylor et al., 2014).

Due to major river inflows and weak tidal influence, most of the Galveston Bay estuary may experience prolonged low salinity throughout the water column with heavy precipitation (Du et al., 2019); however, the HSC acts as a conduit for tidal waters. Water stratification in channels can lead to differences as large as $15 \mathrm{ppt}$ between the surface and bottom (Bechtel and Copeland, 1970). After Hurricane Harvey, the average midcolumn salinity in channel habitat was more than 4 ppt higher than in open bay habitat, and habitat-specific encounter rates suggested that dolphins moved toward deeper channels (Fazioli and Mintzer, 2020). However, studies in Pensacola Bay, FL and Barataria Bay, LA found that dolphins exposed to low salinity did not move to areas with higher salinities (McBrideKebert and Toms, 2021; Takeshita et al., 2021). Future studies should examine fine-scale habitat distribution of dolphins within the Galveston Bay estuary to further evaluate movements in response to flooding.

It is important to reiterate that some dolphins remained in the study area during each freshwater event. Preliminary site fidelity analyses suggest that there is a resident population of dolphins that utilize UGB regularly as a portion of their range (Fazioli et al., 2017). Dolphins that demonstrate high site fidelity within an estuary are known to move within their home range as a response to environmental factors, but are unlikely to abandon it, even in unfavorable conditions (Mazzoil et al., 2008; Wells et al., 2017; McBride-Kebert and Toms, 2021; Takeshita et al., 2021). Dolphins are physiologically adapted to inhabit brackish to oceanic coastal waters with salinities that typically range from 15 to 35 ppt (Ewing et al., 2017; McClain et al., 2020; Booth and Thomas, 2021). Those that remain in an area subject to a low salinity event may suffer from freshwater intoxication due to oral ingestion and/or skin absorption, leading to serious negative health consequences (Ewing et al., 2017; Deming et al., 2020; Duignan et al., 2020; Fazioli and Mintzer, 2020; McClain et al., 2020; McBride-Kebert and Toms, 2021). Effects of freshwater exposure on dolphins can include development of hydropic degeneration and ulcerative or erosive skin lesions (e.g., Wilson et al., 1999; Mullin et al., 2015; Duignan et al., 2020; Fazioli and Mintzer, 2020; McClain et al., 2020; Toms et al., 2020; Townsend, 2020; Takeshita et al., 2021), corneal edema (Deming et al., 2020), and changes in blood chemistry and electrolytes (Ewing et al., 2017; Deming et al., 2020; McClain et al., 2020). Some of these effects were evident when both prevalence and extent of skin lesions increased significantly in the study population after Hurricane Harvey (Fazioli and Mintzer, 2020). Further effects on dolphin health and mortality are likely to occur during freshwater events due to the energetic costs associated with reduced prey availability (Meager and Limpus, 2014; Booth and Thomas, 2021).

Dolphins in UGB are subject to multiple stressors and could be particularly vulnerable to the effects of freshwater (Booth and Thomas, 2021). Epidermal degeneration may heighten exposure to disease and infection, compounded by the increase of pollutants, bacteria and other toxic substances in the water during flood events (Wilson et al., 1999; Kiaghadi and Rifai, 2019; Bacosa et al., 2020; Steichen et al., 2020). Additionally, immunosuppression and adrenal compromise caused by longterm accumulation of toxic pollutants and exposure to petroleum products (Schwacke et al., 2012, 2014) could make dolphins more susceptible to secondary infection and less capable of physiologically adapting to salinity changes in their environment (McClain et al., 2020). More research is needed to understand the population-level effects of freshwater events in Galveston Bay, and to identify which individuals or groups (i.e., age classes and residents) are more susceptible, either physiologically or due to high site fidelity and reluctance to leave the affected area.

In the United States, coastal bottlenose dolphin stocks are protected under the Marine Mammal Protection Act of 1972, and the results of this study have implications for the management of the Galveston Bay stock. Importantly, this study revealed that dolphins use UGB year-round. Continued monitoring is warranted to identify changes in the survival and health of UGB dolphins related to ongoing threats. Seafood advisories, legacy contaminants in sediment, chemical and hydrocarbon spills, and flood events, all make UGB a "high-risk" environment [Houston Advanced Research Center (HARC), 2020; and sources therein]. Heavy precipitation and flood events are expected to increase in intensity due to global climate change (Easterling et al., 2000; Knutson et al., 2010), and as occurred with Hurricane Harvey, these could severely decrease the salinity of Galveston Bay dolphin habitat (Fazioli and Mintzer, 2020). Furthermore, future dredging and infrastructure projects, including the planned widening of the HSC and proposed storm barriers (e.g., USACE and TGLO, 2021), could have considerable short and long-term effects (e.g., noise exposure, increased vessel traffic, and habitat availability). The proposed "Galveston Bay Storm Surge Barrier System" could lead to temporary or permanent changes to salinity and prey assemblages (USACE and TGLO, 2021). The results of our study, emphasizing the year-round presence of dolphins and the importance of salinity, should be considered during the development of these large-scale projects. Mitigation measures will likely be necessary to protect this population, but more information is needed on how dolphins utilize Galveston Bay, the nearshore waters of the Gulf of Mexico, and other Texas bays to identify critical habitats utilized during cooler months and freshwater events.

\section{DATA AVAILABILITY STATEMENT}

The raw data supporting the conclusions of this article will be made available by the authors, without undue reservation. 


\section{ETHICS STATEMENT}

This work was conducted under the National Oceanic and Atmospheric Administration Fisheries (NOAA Fisheries) Scientific Research Permit \#18881. Animals were not handled during our field work, so no further reviews were necessary for this non-invasive work.

\section{AUTHOR CONTRIBUTIONS}

VM and KF designed and executed the study and wrote the manuscript. KF collected and managed the data. VM performed the analysis. Both authors contributed to the article and approved the submitted version.

\section{FUNDING}

This work was conducted by the Galveston Bay Dolphin Research Program (GDRP), a cooperative agreement between the Environmental Institute of Houston at the University of Houston - Clear Lake and the Galveston Bay Foundation. Parts of this study were completed with grant support from the Gulf of Mexico Alliance, the SeaWorld Busch Gardens

\section{REFERENCES}

Adams, J. D., Speakman, T., Zolman, E., and Schwacke, L. H. (2006). Automating image matching, cataloging, and analysis for photo-identification research. Aquat. Mamm. 32, 374-384. doi: 10.1578/AM.32.3.2006.374

Bacosa, H. P., Steichen, J., Kamalanathan, M., Windham, R., Lubguban, A., Labonté, J. M., et al. (2020). Polycyclic aromatic hydrocarbons (PAHs) and putative PAH-degrading bacteria in Galveston Bay, TX (USA), following Hurricane Harvey (2017). Environ. Sci. Pollut. Res. 27, 34987-34999. doi: 10.1007/s11356-020-09754-5

Bechtel, T. J., and Copeland, B. (1970). Fish species diversity indices as indicators of pollution in Galveston Bay, Texas. Contrib. Mar. Sci. 15, 103-132.

Blaylock, R. A., and Hoggard, W. (1994). Preliminary estimates of bottlenose dolphin abundance in southern US Atlantic and Gulf of Mexico continental shelf waters. NOAA Tech. Mem. 356:10.

Booth, C., and Thomas, L. (2021). An expert elicitation of the effects of low salinity water exposure on bottlenose dolphins. Oceans 2, 179-192. doi: 10 . 3390/oceans 2010011

Boyd, S. (2011). Mullet - Fishy Facts. Texas Saltwater Fishing Magazine. Available online at: https://www.texassaltwaterfishingmagazine.com/fishing/education/ fishy-facts/mullet (accessed October 18, 2021).

Bräger, S., Würsig, B., Acevedo, A., and Henningsen, T. (1994). Association patterns of bottlenose dolphins (Tursiops truncatus) in Galveston Bay, Texas. J. Mammal. 75, 431-437. doi: 10.2307/1382564

Carmichael, R. H., Graham, W. M., Aven, A., Worthy, G., and Howden, S. (2012). Were multiple stressors a 'perfect storm' for northern Gulf of Mexico bottlenose dolphins (Tursiops truncatus) in 2011? PLoS One 7:e41155. doi: 10.1371/ journal.pone.0041155

Deming, A. C., Wingers, N. L., Moore, D. P., Rotstein, D., Wells, R. S., Ewing, R., et al. (2020). Health impacts and recovery from prolonged freshwater exposure in a common bottlenose dolphin (Tursiops truncatus). Front. Vet. Sci. 7:235. doi: $10.3389 /$ fvets.2020.00235

Du, J., Park, K., Dellapenna, T. M., and Clay, J. M. (2019). Dramatic hydrodynamic and sedimentary responses in Galveston Bay and adjacent inner shelf to Hurricane Harvey. Sci. Total Environ. 653, 554-564. doi: 10.1016/j.scitotenv. 2018.10.403
Conservation Fund, the SeaWorld Busch Gardens Emergency Fund, Restore America's Estuaries, the Trull Foundation, and individual GDRP donors.

\section{ACKNOWLEDGMENTS}

We are grateful to the numerous people that contribute to the field work, logistical support, data organization and management that makes this long-term research possible. George Guillen, Jenny Oakley, Sherah McDaniel, Shelby Yahn, Robert Stokes, and GDRP volunteers provided this important support. Thank you to James Colee, with the University of Florida's Institute of Food and Agricultural Sciences statistical consulting unit, for his guidance on the statistical analysis. We also thank Randy Wells and the Chicago Zoological Society's Sarasota Dolphin Research Program for their long-standing support and mentorship.

\section{SUPPLEMENTARY MATERIAL}

The Supplementary Material for this article can be found online at: https://www.frontiersin.org/articles/10.3389/fmars. 2021.754686/full\#supplementary-material

Duignan, P. J., Stephens, N. S., and Robb, K. (2020). Fresh water skin disease in dolphins: a case definition based on pathology and environmental factors in Australia. Sci. Rep. 10, 1-17. doi: 10.1038/s41598-020-78 $858-2$

Easterling, D. R., Meehl, G. A., Parmesan, C., Changnon, S. A., Karl, T. R., and Mearns, L. O. (2000). Climate extremes: observations, modeling, and impacts. Science 289, 2068-2074. doi: 10.1126/science.289.5487. 2068

Ewing, R. Y., Mase-Guthrie, B., McFee, W., Townsend, F., Manire, C. A., Walsh, M., et al. (2017). Evaluation of serum for pathophysiological effects of prolonged low salinity water exposure in displaced bottlenose dolphins (Tursiops truncatus). Front. Vet. Sci. 4:80. doi: 10.3389/fvets.2017.00080

Fazioli, K., and Mintzer, V. (2020). Short-term effects of Hurricane Harvey on bottlenose dolphins (Tursiops truncatus) in upper Galveston Bay, TX. Estua. Coast 43, 1013-1031. doi: 10.1007/s12237-020-00751-y

Fazioli, K. L., Hofmann, S., and Wells, R. (2006). Use of Gulf of Mexico coastal waters by distinct assemblages of bottlenose dolphins (Tursiops truncatus). Aquat. Mamm. 32, 212-222. doi: 10.1578/AM.32.2.20 06.212

Fazioli, K., Mintzer, V., Guillen, G., and Loe, S. (2016). Texas' Estuarine Bottlenose Dolphins: Addressing Knowledge Gaps in Galveston Bay. New Orleans, LA: America's Estuaries 8th National Summit on Coastal and Estuarine Restoration. Available online at: https://galvestonbaydolphin.org/wp-content/ uploads/2020/05/fazioli-etal-2016-rae.pdf (accessed on October 18, 2021).

Fazioli, K., Mintzer, V., and Guillen, G. (2017). "Site fidelity of bottlenose dolphins (Tursiops truncatus) in a highly-industrialized estuary," in Proceeding of the Society for Marine Mammalogy, 22nd Biennial Conference on the Biology of Marine Mammals, (Canada). Available online at: https://galvestonbaydolphin. org/wp-content/uploads/2020/05/fazioli-mintzer-guillen-2017-smm.pdf (accessed October 18, 2021).

Fernandez, S., and Hohn, A. A. (1998). Age, growth, and calving season of bottlenose dolphins, Tursiops truncatus, off coastal Texas. Fish. Bull. 96, 357365.

Fertl, D. C. (1994). Occurrence, Movements, and Behavior of Bottlenose Dolphins (Tursiops truncatus) in Association with the Shrimp Fishery in Galveston Bay, Texas. Ph. D, Thesis. Galveston (TX): Texas A\&M University. 
GBRC (2021). Galveston Bay Report Card. Galveston Bay Foundation and Houston Advanced Research Center. Available online at: www.galvbaygrade.org (accessed August 6, 2021)

Greenwood, M. F., Stevens, P. W., and Matheson, R. E. Jr. (2006). Effects of the 2004 hurricanes on the fish assemblages in two proximate southwest Florida estuaries: change in the context of interannual variability. Estuaries Coasts 29, 985-996. doi: 10.1007/BF02798660

Hastie, G. D., Wilson, B., Wilson, L., Parsons, K. M., and Thompson, P. M. (2006). Functional mechanisms underlying cetacean distribution patterns: hotspots for bottlenose dolphins are linked to foraging. Mar. Biol. 144, 397-403. doi: 10.1007/s00227-003-1195-4

Hayes, S. A., Josephson, E., Maze-Foley, K., and Rosel, P. E. (2019). US Atlantic and Gulf of Mexico marine mammal stock assessments-2018. NOAA Tech. Mem. 258, 298.

Heithaus, M. R., and Dill, L. M. (2006). Does tiger shark predation risk influence foraging habitat use by bottlenose dolphins at multiple spatial scales? Oikos 114, 257-264. doi: 10.1111/j.2006.0030-1299.14443.x

Henningsen, T., and Würsig, B. (1991). "Bottle-nosed dolphins in Galveston Bay, Texas: numbers and activities," in Proceeding of the European Research on Cetaceans-5 - Proceedings of the Fifth Annual Conference of the European Cetacean Society, (Norway), 21-23.

Hornsby, F. E., McDonald, T. L., Balmer, B. C., Speakman, T. R., Mullin, K. D., Rosel, P. E., et al. (2017). Using salinity to identify common bottlenose dolphin habitat in Barataria Bay, Louisiana, USA. Endanger. Species Res. 33, 181-192. doi: 10.3354 /esr00807

Houston Advanced Research Center (HARC) (2020). State of the Bay: A Characterization of the Galveston Bay Ecosystem, 4th Edn. Available online at: https://stateofgalvbay.org/ (accessed October 18, 2021).

Huther, K. D. (2010). An Examination of Bottlenose Dolphin (Tursiops truncatus) abundances in relation to environmental factors and risks. Ph. D, Thesis. Charleston (SC): College of Charleston.

Irvine, B., Scott, M., Wells, R., and Kaufmann, J. (1981). Movements and activities of the Atlantic bottlenose dolphin, Tursiops truncatus, near Sarasota, Florida. Fish. Bull. 79, 671-688.

Jones, S. III (1988). Survey of the Atlantic Bottlenose Dolphin (Tursiops truncatus) population near Galveston, Texas. Ph. D, Thesis. Galveston (TX): Texas A\&M University.

Kennish, M. J. (2002). Environmental threats and environmental future of estuaries. Environ. Conserv. 29, 78-107. doi: 10.1017/S037689290200 0061

Kiaghadi, A., and Rifai, H. (2019). Physical, chemical, and microbial quality of floodwaters in Houston following Hurricane Harvey. J. Environ. Sci. Technol. 53, 4832-4840. doi: 10.1021/acs.est.9b00792

Knutson, T. R., McBride, J. L., Chan, J., Emanuel, K., Holland, G., Landsea, C., et al. (2010). Tropical cyclones and climate change. Nat. Geosci. 3, 157-163. doi: $10.1038 /$ ngeo779

Leatherwood, S., and Reeves, R. R. (2012). The Bottlenose Dolphin. Cambridge, MA: Academic Press, Inc.

Lynn, S. K., and Würsig, B. (2002). Summer movement patterns of bottlenose dolphins in a Texas Bay. Gulf Mex. Sci. 20:3. doi: 10.18785/goms.2001.03

Maze, K., and Würsig, B. (1999). Bottlenosed dolphins of San Luis Pass, Texas: occurrence patterns, site-fidelity, and habitat use. Aquat. Mamm. 25, 91-104.

Mazzoil, M., Reif, J. S., Youngbluth, M., Murdoch, M. E., Bechdel, S. E., Howells, E., et al. (2008). Home ranges of bottlenose dolphins (Tursiops truncatus) in the Indian River Lagoon, Florida: environmental correlates and implications for management strategies. EcoHealth 5, 278-288. doi: 10.1007/s10393-008-0 194-9

McBride-Kebert, S., and Toms, C. N. (2021). Common bottlenose dolphin, Tursiops truncatus, behavioral response to a record-breaking flood event in Pensacola Bay, florida. J. Zool. and Bot. Gard. 2, 351-369. doi: 10.3390/ jzbg2030025

McClain, A. M., Daniels, R., Gomez, F. M., Ridgway, S. H., Takeshita, R., Jensen, E. D., et al. (2020). Physiological effects of low salinity exposure on bottlenose dolphins (Tursiops truncatus). J. Zool. and Bot. Gard. 1, 61-75. doi: 10.3390/ jzbg1010005

McHugh, M. B. (1989). Population Numbers and Feeding Behavior of the Atlantic Bottlenose Dolphin (Tursiops truncatus) near Aransas Pass, Texas. Ph. D, Thesis. Austin (TX): University of Texas at Austin.
Meager, J. J., and Limpus, C. (2014). Mortality of inshore marine mammals in eastern australia is predicted by freshwater discharge and air temperature. PLoS One 9:e94849. doi: 10.1371/journal.pone.0094849

Meagher, E. M., McLellan, W. A., Westgate, A. J., Wells, R. S., Blum, J. E., and Pabst, D. A. (2008). Seasonal patterns of heat loss in wild bottlenose dolphins (Tursiops truncatus). J. Comp. Physiol. B 178, 529-543. doi: 10.1007/s00360-007-0245-5

Moreno, M. P. T. (2005). Environmental Predictors of Bottlenose Dolphin Distribution and Core Feeding Densities in Galveston Bay, Texas. Ph. D, Thesis. Galveston (TX): Texas A\&M University.

Moreno, P., and Mathews, M. (2018). Identifying foraging hotspots of bottlenose dolphins in a highly dynamic system: a method to enhance conservation in estuaries. Aquat. Mammal. 44:694. doi: 10.1578/AM.44.6.2018.694

Muggeo, V. M. (2008). Segmented: an R package to fit regression models with broken-line relationships. $R$ News 8, 20-25.

Mullin, K., Barry, K. P., Sinclair, C., Litz, J. A., Maze-Foley, K., Fougeİres, E. M., et al. (2015). Common bottlenose dolphins (Tursiops truncatus) in Lake Pontchartrain, Louisiana, 2007 to mid-2014. NOAA Tech. Mem. 673:43.

Orlando, S. P., Rozas, L. P., Ward, G. H., and Klein, C. J. (1993). Salinity Characteristics of Gulf of Mexico estuaries. Silver Spring, MD: National Oceanic and Atmospheric Administration, Office of Ocean Resources Conservation and Assessment, 209.

Phillips, N. M., and Rosel, P. E. (2014). A method for prioritizing research on common bottlenose dolphin stocks through evaluating threats and data availability: development and application to bay, sound and estuary stocks in Texas. NOAA Tech. Mem. 665:146.

Piwetz, S. (2019). Common bottlenose dolphin (Tursiops truncatus) behavior in an active narrow seaport. PLoS One 14:e0211971. doi: 10.1371/journal.pone. 0211971

R Core Team (2020). R: A Language and Environment for Statistical Computing. Vienna: R Foundation for Statistical Computing. Available online at: https: //www.R-project.org/.

Ronje, E., Whitehead, H., Barry, K., Piwetz, S., Struve, J., Lecours, V., et al. (2020). Abundance and occurrence of common bottlenose dolphins (Tursiops truncatus) in three estuaries of the northwestern Gulf of Mexico. Gulf Caribb. Res. 31, 18-34. doi: $10.18785 / \mathrm{gcr}$. 3101.09

Rosel, P., Mullin, K., Garrison, L., Schwacke, L., Adams, J., Balmer, B., et al. (2011). Photoidentification capture-mark-recapture techniques for estimating abundance of bay, sound and estuary populations of bottlenose dolphins along the US East Coast and Gulf of Mexico: a workshop report. NOAA Tech. Mem. 621:30.

Schwacke, L. H., Smith, C. R., Townsend, F. I., Wells, R. S., Hart, L. B., Balmer, B. C., et al. (2014). Health of common bottlenose dolphins (Tursiops truncatus) in Barataria Bay, Louisiana, following the Deepwater Horizon oil spill. Environ. Sci. Technol. 48, 93-103. doi: 10.1021/es403610f

Schwacke, L. H., Zolman, E. S., Balmer, B. C., De Guise, S., George, R. C., Hoguet, J., et al. (2012). Anaemia, hypothyroidism and immune suppression associated with polychlorinated biphenyl exposure in bottlenose dolphins (Tursiops truncatus). Proc. Royal Soc. B 279, 48-57. doi: 10.1098/rspb.2011.0665 Scott, M. D., Wells, R. S., and Irvine, A. B. (1990). "A long-term study of bottlenose dolphins on the west coast of florida," in The Bottlenose Dolphin, eds. S. Leatherwood and R. R. Reeves (Cambridge, MA: Academic Press, University of California), 235-244. . doi: 10.1016/B978-0-12-440280-5.50015-9

Shane, S. H. (1980). Occurrence, movements, and distribution of bottlenose dolphin, Tursiops truncatus, in southern Texas. Fish. Bull. 78, 593-601.

Steichen, J. L., Labonté, J. M., Windham, R., Hala, D., Kaiser, K., Setta, S., et al. (2020). Microbial, physical, and chemical changes in Galveston Bay following an extreme flooding event, Hurricane Harvey. Front. Mar. Sci. 7:186. doi: 10.3389/fmars.2020.00186

Takeshita, R., Balmer, B. C., Messina, F., Zolman, E. S., Thomas, L., Wells, R. S., et al. (2021). High site-fidelity in common bottlenose dolphins despite low salinity exposure and associated indicators of compromised health. PLoS One 16:e0258031. doi: 10.1371/journal.pone.025 8031

Taylor, M. D., van der Meulen, D. E., Ives, M. C., Walsh, C. T., Reinfelds, I. V., and Gray, C. A. (2014). Shock, stress or signal? Implications of freshwater flows for a top-level estuarine predator. PLoS One 9:e95680. doi: 10.1371/journal.pone. 0095680 
Tolan, J. M. (2007). El Niño-southern oscillation impacts translated to the watershed scale: estuarine salinity patterns along the Texas gulf coast, 1982 to 2004. Estuar. Coast. Shelf Sci. 72, 247-260. doi: 10.1016/j.ecss.2006.10.018

Toms, C. N., Stone, T., and Och-Adams, T. (2020). Visual-only assessments of skin lesions on free-ranging common bottlenose dolphins (Tursiops truncatus): reliability and utility of quantitative tools. Mar. Mamm. Sci. 36, 744-773. doi: $10.1111 / \mathrm{mms} .12670$

Townsend, C. I. (2020). "Chapter seven: miscellaneous-prolonged freshwater exposure," in Atlas of Skin Diseases of Small Cetaceans, eds F. I. Townsend and L. Staggs 62-65.

TWPD (2002). The Texas Shrimp Fishery. A Report to the Governor and the 77th Legislature of Texas. Texas Parks and Wildlife Department. Available online at: https://tpwd.texas.gov/publications/pwdpubs/media/pwd_ rp_v3400_857.pdf (accessed August 6, 2021).

TWDB (2021). Water Data for Texas, Texas Water Development Board. Available online at https://waterdatafortexas.org (accessed August 6, 2021).

Urian, K. W., and Wells, R. S. (1996). Bottlenose Dolphin Photo-Identification Workshop: March 21-22, 1996. Charleston, SC: NOAA Technical Memorandum NMFS-SEFSC-393.

Urian, K., Duffield, D., Read, A., Wells, R., and Shell, E. (1996). Seasonality of reproduction in bottlenose dolphins, Tursiops truncatus. J. Mammal. 77, 394-403. doi: 10.2307/1382814

Urian, K., Gorgone, A., Read, A., Balmer, B., Wells, R. S., Berggren, P., et al. (2015). Recommendations for photo-identification methods used in capture recapture models with cetaceans. Mar. Mamm. Sci. 31:24. doi: 10.1111/mms.12141

Urian, K. W., Hofmann, S., Wells, R. S., and Read, A. J. (2009). Fine-scale population structure of bottlenose dolphins (Tursiops truncatus) in Tampa Bay, Florida. Mar. Mamm. Sci. 25, 619-638. doi: 10.1111/j.1748-7692.2009.00284.x

USACE, and TGLO (2021). Coastal Texas Protection and Restoration Feasibility Study - Final Environmental Impact Statement, US Army Core of Engineers Galveston District and the Texas General Land Office. Available online at https://www.swg.usace.army.mil/Portals/26/Coastal\%20Texas\%20Protection\% 20and\%20Ecosystem\%20Restoration\%20Feasibility\%20Study_Aug2021_ FEIS_1.pdf (accessed September 21, 2021)

Vollmer, N. L., and Rosel, P. (2013). A review of common bottlenose dolphins (Tursiops truncatus truncatus) in the northern Gulf of Mexico: population biology, potential threats, and management. Southeast. Nat. 12, 1-43.

Ward, G. H., and Armstrong, N. E. (1992). Ambient Water and Sediment Quality of Galveston Bay: Present Status and Historical Trends. Galveston Bay National Estuary Program Publication GBNEP-22. Webster, TX.

Wells, R. S., and Scott, M. D. (2018). "Bottlenose dolphin, Tursiops truncatus, common bottlenose dolphin," in Encyclopedia of Marine Mammals, eds B. Wursig, J. G. M. Thewissen, and K. M. Kovacs (Academic Press, Inc), 118-125. doi: 10.1016/B978-0-12-804327-1.00072-8
Wells, R. S., Bassos, M. K., Urian, K. W., Carr, W. J., and Scott, M. D. (1996). Low-Level Monitoring of Bottlenose Dolphins, Tursiops truncatus, in Charlotte Harbor, Florida 1990-1994. Washington, DC: NOAA Technical Memorandum NMFS-SEFSC. doi: 10.5962/bhl.title.4168

Wells, R. S., Schwacke, L. H., Rowles, T. K., Balmer, B. C., Zolman, E., Speakman, T., et al. (2017). Ranging patterns of common bottlenose dolphins Tursiops truncatus in Barataria Bay, Louisiana, following the Deepwater Horizon oil spill. Endanger. Species Res. 33, 159-180. doi: 10.3354/esr0 0732

Wilson, B., Arnold, H., Bearzi, G., Fortuna, C. M., Gaspar, R., Ingram, S., et al. (1999). Epidermal diseases in bottlenose dolphins: impacts of natural and anthropogenic factors. Proc. R. Soc. B. 266, 1077-1083. doi: 10.1098/rspb.1999. 0746

Wilson, B., Thompson, P., and Hammond, P. (1997). Habitat use by bottlenose dolphins: seasonal distribution and stratified movement patterns in the Moray Firth, Scotland. J. Appl. Ecol. 34, 1365-1374. doi: 10.2307/240 5254

Würsig, B., and Würsig, M. (1977). The photographic determination of group size, composition, and stability of coastal porpoises (Tursiops truncatus). Science 198, 755-756. doi: 10.1126/science.198.4318.755

Yeates, L. C., and Houser, D. S. (2008). Thermal tolerance in bottlenose dolphins (Tursiops truncatus). J. Exp. Biol. 211, 3249-3257. doi: 10.1242/jeb.020610

Youngblood, K. A. (2010). Fouling the Water: An Environmental History of Galveston Bay. Houston (TX): University of Houston.

Author Disclaimer: The views expressed are those of the authors and do not necessarily reflect the views of supporting organizations.

Conflict of Interest: The authors declare that the research was conducted in the absence of any commercial or financial relationships that could be construed as a potential conflict of interest.

Publisher's Note: All claims expressed in this article are solely those of the authors and do not necessarily represent those of their affiliated organizations, or those of the publisher, the editors and the reviewers. Any product that may be evaluated in this article, or claim that may be made by its manufacturer, is not guaranteed or endorsed by the publisher.

Copyright (C) 2021 Mintzer and Fazioli. This is an open-access article distributed under the terms of the Creative Commons Attribution License (CC BY). The use, distribution or reproduction in other forums is permitted, provided the original author(s) and the copyright owner(s) are credited and that the original publication in this journal is cited, in accordance with accepted academic practice. No use, distribution or reproduction is permitted which does not comply with these terms. 